\section{Revista de la \\ Universidad del Thulia}

Fundada en 1947 por el Dr. Jesúns Enrique Lossada

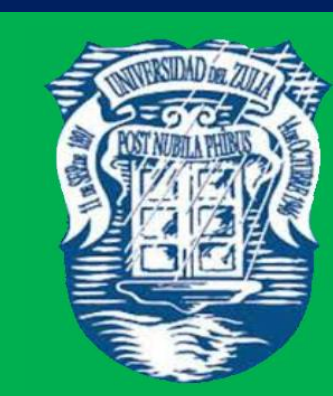

Ciencias del

Algreo

Ingemieria

y Teemología

\section{Aกัต 11 No 29}

Enero - Abril 2021

Tercera Época

Maracaibo-Venezuela 
REVISTA DE LA UNIVERSIDAD DEL ZULIA. 3ª época. Año 11 Nº 29, 2020

Tatyana M. Yarkova /// Illegal economic phenomena in the Russian agricultural sector, 276-284

\title{
Illegal economic phenomena in the Russian agricultural sector
}

Tatyana M. Yarkova*

\begin{abstract}
The current unstable market situation in Russia forces undesirable measures to be taken, mainly in the field of tax legislation for economic entities in the agricultural sector. This becomes a prior factor for the development of economic crime and the development of illegal phenomena. In recent years, there has been an increase in these crimes in the country. The agricultural sector of the Russian economy, as well as other countries, requires the availability of state financial support. However, during almost the entire post-Soviet period, a partial theft of state funds allocated to support and develop agricultural sectors can be observed under free market conditions. Such a problem exists everywhere in Russia. Existing methods of supervision and control over the use of budget allocations do not give the expected effect. In the context of such a negative situation, there is a need to develop effective methodological tools to assess the effectiveness and integrity of the use of budget funds for the agricultural sector, the algorithm of which is quite accessible and involves the use of scientific and practical methods, experience and knowledge of experts in the field of agriculture. This article aims to identify patterns of economic crime in agricultural and livestock production, and to propose methods for the evaluation and monitoring of public funds to Russian agricultural entities.
\end{abstract}

KEY WORDS: economy, agricultural sector, illegal phenomena, state support.

*Doctor of Economics, Professor, Department of Agricultural Production Organization, Federal State Budgetary Educational Institution of Higher Education "Perm State AgroTechnological Univesity named after Academician D.N. Pryanishnikov", Perm, Russia, tanyayarkova@ya.ru 
REVISTA DE LA UNIVERSIDAD DEL ZULIA. 3ª época. Año 11 Nº 29, 2020

Tatyana M. Yarkova /// Illegal economic phenomena in the Russian agricultural sector, 276-284

\section{Fenómenos económicos ilegales en el sector agrícola de Rusia}

\section{RESUMEN}

La inestable situación actual del mercado en Rusia obliga a tomar medidas indeseables, principalmente en el campo de la legislación fiscal para las entidades económicas del sector agrícola. Esto se convierte en un factor previo para el desarrollo del delito económico y el desarrollo de fenómenos ilegales. En los últimos años, se observa un crecimiento de estos delitos en el país. El sector agrario de la economía rusa, así como otros países, requiere la disponibilidad de apoyo financiero estatal. Sin embargo, durante casi todo el período postsoviético, se puede observar un robo parcial de fondos estatales asignados para apoyar y desarrollar sectores agrícolas en las condiciones del libre mercado. Tal problema existe en todas partes en Rusia. Los métodos existentes de supervisión y control sobre el uso de las asignaciones presupuestarias no dan el efecto esperado. En el contexto de una situación tan negativa, existe la necesidad de desarrollar herramientas metodológicas efectivas para evaluar la efectividad y la integridad del uso de fondos presupuestarios para el sector agrícola, cuyo algoritmo es bastante accesible e implica el uso de métodos científicos y prácticos, experiencia y conocimiento de expertos en el campo de la agricultura. Este artículo tiene como propósito identificar patrones de delitos económicos en la producción agrícola y ganadera, y proponer métodos para la evaluación y seguimiento de fondos públicos a entidades agrícolas rusas.

PALABRAS CLAVE: economía, sector agrícola, fenómenos ilegales, apoyo estatal.

\section{Introduccion}

A well-known fact and problem is the presence of illegal phenomena in the agrarian sphere, whose origin is associated primarily with the availability of large material and financial flows. Such flows are the result of state (federal, regional and municipal) support, without which it is simply impossible to ensure the solution of extremely important socio-economic problems.

In this regard, particularly close attention should be paid to the reproduction processes between the entities of the agro-industrial complex of the region, which are based on the use of natural resources and capital, the movement of material and financial flows. They are of real mercenary interest for a person or a whole group of 
REVISTA DE LA UNIVERSIDAD DEL ZULIA. 3ª época. Año 11 Nº 29, 2020

Tatyana M. Yarkova /// Illegal economic phenomena in the Russian agricultural sector, 276-284

people. Therefore, one should not underestimate the detrimental influence of the illegal economy:

- Direct impact on the economic development of agricultural business in the region;

- Indirect influence on the social development of rural residents and rural areas themselves (Panin, 2012).

At a first glance, the question arises: "what interest can a priori unprofitable agricultural sector of the economy cause?" The answer to it is quite obvious and lies in the fact that government investment in this sector of the economy is growing annually, while monitoring their use is not effective enough. Along with this, it should be added that it is attractive to put into the shade a number of natural resources used in agriculture and forestry, for example, land, forest, water bodies, etc.

In this article we have set ourselves two objectives: a) identify patterns of economic crime in agricultural and livestock production; b) propose methods for the evaluation and monitoring of public funds to Russian agricultural entities. To achieve these objectives, we rely on consulting specialized literature on the subject of economic crime control.

\section{Analysis}

The statement is absolutely true that there is a direct and close relationship between the level of economic development of the region and the level of the illegal economy. This is due to an elementary pattern: the more financial resources are involved in a particular sector of the economy, the greater is the interest of "illegal" structures in transferring part of the capital from the official economy of this sphere to the illegal one.

The modern economy is subject to the influence of multiple factors and conditions, which in the agricultural sector, in part, can act as prerequisites for the development of economic crimes (fig. 1).

In the view of many people, the illegal economy is associated with tax evasion through falsification of financial statements. However, in fact, its scope is much wider and can be represented by: illegal entrepreneurship; legalization of proceeds of crime; 
REVISTA DE LA UNIVERSIDAD DEL ZULIA. 3ª época. Año 11 N² 29, 2020

Tatyana M. Yarkova /// Illegal economic phenomena in the Russian agricultural sector, 276-284

offenses in the field of financing business entities; illegal monopolization of sales markets, and so on.

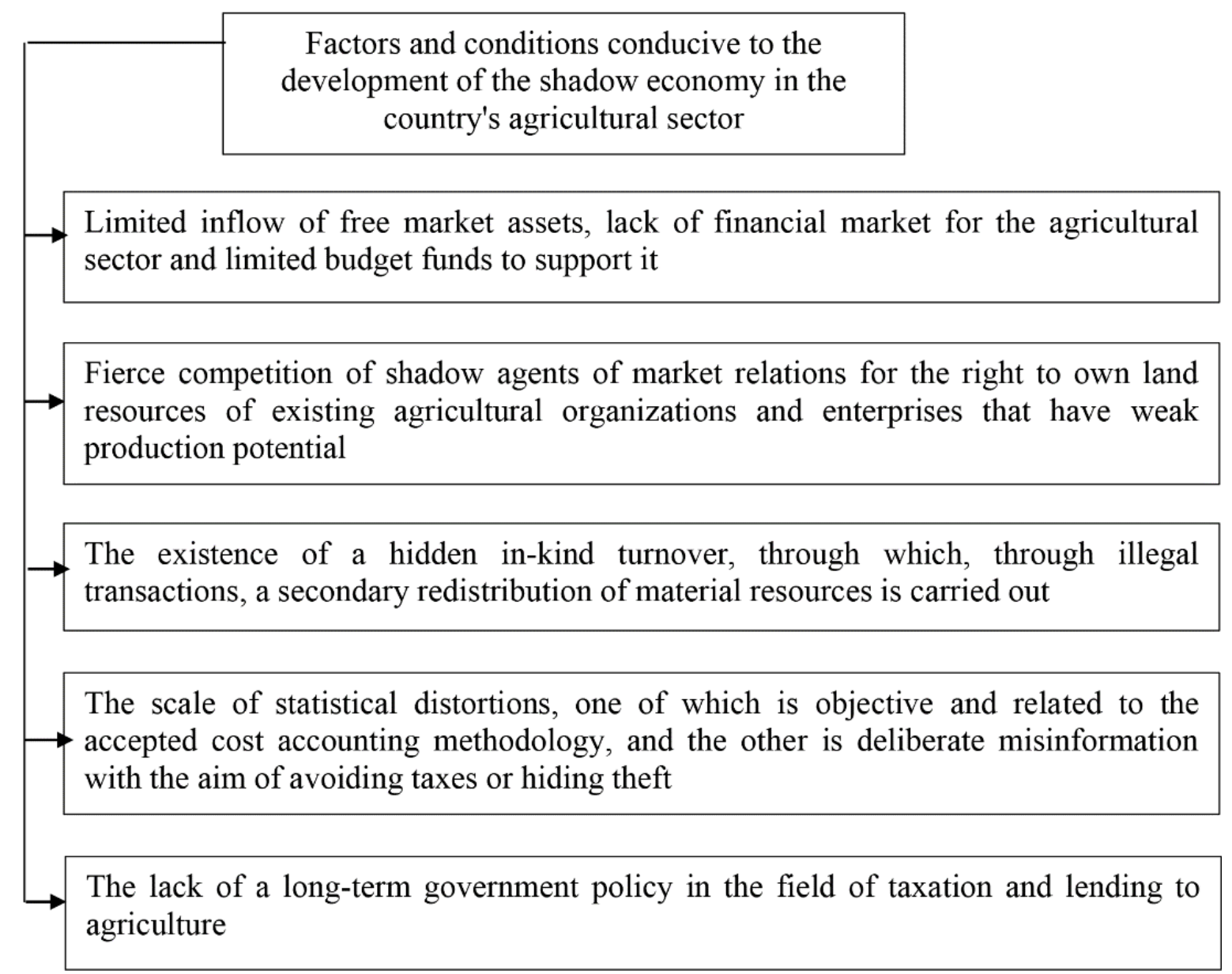

Figure 1. Factors and conditions for the development of illegal phenomena in the Russian agricultural sector (Trotsenko, 2019)

The instability of modern tax legislation in Russia gives rise to the tendency of a business executive to seek tax evasion and other obligatory payments to state extrabudgetary funds. Especially in recent years, individual entrepreneurs have suffered, who are forced to minimize their financial losses through double-entry bookkeeping. Such tax law violations in Russia are gaining momentum. There is an outflow of enterprises from legal business to the illegal one, and the illegal sector as a whole is also growing (Dadalko, 2010; Repin, 2015).

It is known that agricultural organizations are almost entirely grant-aided and subsidized. Due to this "status", farmers not only compensate for losses in agricultural production, but also compensate for part of the cost of production, for example, milk, 
REVISTA DE LA UNIVERSIDAD DEL ZULIA. 3ª época. Año 11 N² 29, 2020

Tatyana M. Yarkova /// Illegal economic phenomena in the Russian agricultural sector, 276-284

meat, etc. from the budget. Existing software tools for the development of agriculture and food markets in Russia also involve the development and updating of production and economic capacities. In recent years, the construction of dairy farms has become widespread. The need for their construction arose against the background of insufficient production of raw milk for the uninterrupted and sustainable functioning of the domestic market. This direction required significant state financial investments and showed interest among unscrupulous representatives of agribusiness. As a result, the following economic unlawful actions were identified in many Russian regions:

- Theft of state funds, construction materials, as well as abuse of authority by heads of agricultural organizations and representatives of regional Ministries and departments responsible for the targeted use of allocated funds (Gafurov, 2018);

- Abuse of authority and taking bribes by officials. For example, "purchases" of the possibility of concluding an agreement for construction and contracting has become widespread;

- Overstatement according to the estimated documentation of the cost of purchased equipment, building materials, as well as their unreasonably high volumes.

Such crimes characterize many types of capital construction in agriculture and in rural areas in general.

As a result of the increase in the illegal sector, the budgets of particular regions and the country as a whole are being damaged. Amounts that were not received into the budget create the risk of the region and the state not fulfilling their powers to the population. In particular, in 2019 the damage to the budget from tax crimes amounted to 95 billion rubles. One average economic crime can be estimated at about 13 million rubles. At the same time, the share of such tax economic crimes amounts to a little more than $70 \%$, which in some cases can be classified as grave and especially grave and are considered, depending on the damage, by the Code of Criminal Procedure of the Russian Federation (Melnikov, 2012).

The result of such illegal phenomena in the economy is expressed, first of all, in the deformation of the overall market structure, because there is a reduction in the chain in the market mechanism and unfair competition is formed. 
REVISTA DE LA UNIVERSIDAD DEL ZULIA. 3ª época. Año 11 Nº 29, 2020

Tatyana M. Yarkova /// Illegal economic phenomena in the Russian agricultural sector, 276-284

Under the current state support, the following unlawful tools that underlie economic crimes and the illegal economy of the agricultural sector as a whole were widely used (fig. 2).

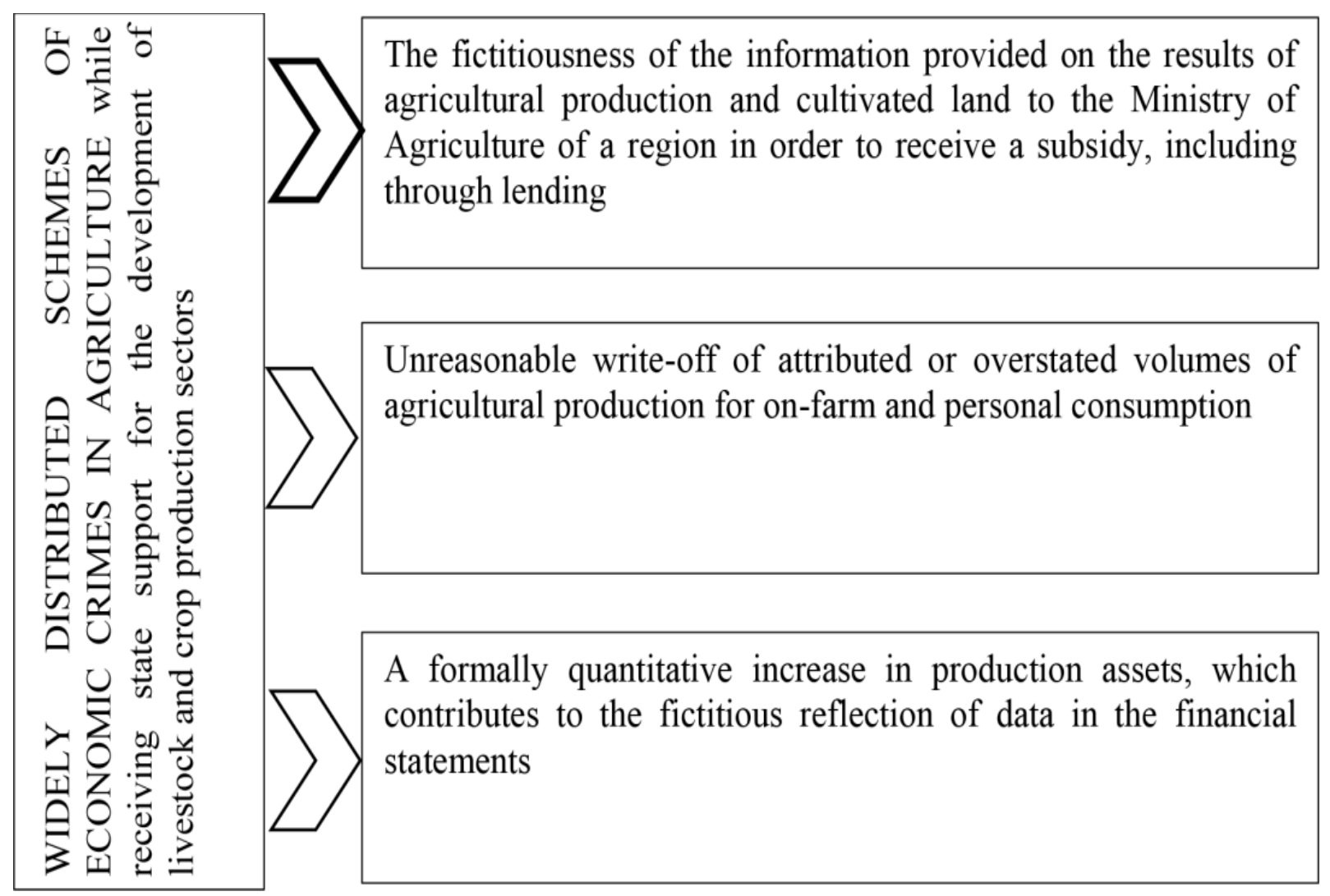

Figure 2. Widely distributed patterns of economic offenses in crop and livestock production.

The schemes that underlie economic crimes in the crop and livestock sectors also contribute to the receipt of completely distorted current, operational and statistical information in the authorities, which subsequently forms the basis for wrong decisions to support and regulate these industries.

In relation to organizations conducting agricultural business, it should be noted that illegal economy expansion gives them additional, but hidden income, which agricultural business entities that conduct their business completely transparently cannot have. However, the illegal economy should not be the motive and encourage the crimes. Consequently, a comfortable state policy with partly loyal tax exposure should be built in relation to agricultural organizations. Such an approach cannot be universal and should be shown in relation to competitive types of economic activity from the 
REVISTA DE LA UNIVERSIDAD DEL ZULIA. 3ª época. Año 11 Nº 29, 2020

Tatyana M. Yarkova /// Illegal economic phenomena in the Russian agricultural sector, 276-284

agricultural sector or may have its own projection on individual agricultural associations and entire territories (Yarkova, 2018; Khairullina and Yarkova, 2018; Khairullina and Yarkova, 2019).

Our decisions are based on the fact that grounds for many economic crimes are state funds which are either not received by the state under the tax regime, or they are wasted inappropriately through crime in whole or in part.

The first step in the fight against illegal processes and phenomena in the agricultural sector should be assessing and monitoring the effectiveness of implementation of state financial investments in this sector of the economy. The evaluation technique is comprehensive and can be implemented in practice in the following algorithm (fig. 3).

Along with the presented assessment methodology for monitoring the effectiveness of the use of budgetary funds, we also propose to use an instrument which provides the monitoring of the legalization of agricultural business.

A direction among many others in the fight against economic crimes in the agroindustrial complex may be a gradual transition to the conditions of widespread cashless payments and multivariate digitalization and automation systems for accounting and control, and in the case of entities with a full production cycle, to an automated cashcontrol system.

The capacity of such areas can be ensured only through the implementation of the universality principle. That is, the business entities themselves, government agencies represented by ministries, departments, agricultural departments, tax services, private farms, farmers, consumers and other participants in the agricultural and food markets should be directly involved in the project.

\section{Conclusion}

The directions recommended for use in practical activities will contribute to the fight against illegal phenomena in the economy of the agricultural sector of the Russian Federation and other countries, as they have a completely universal nature of their impact.

The effectiveness of such measures is global, lasting and will affect the most important components of the socio-economic development of the modern state. 


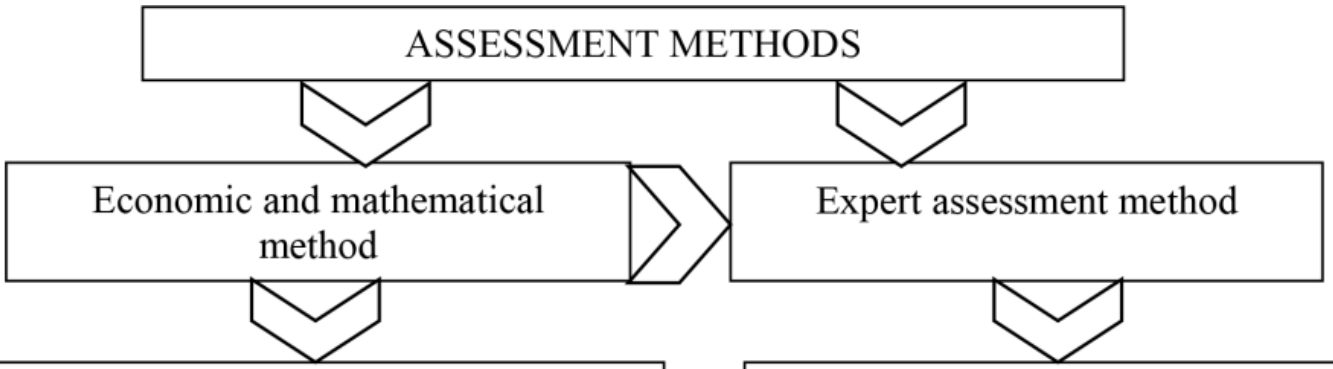

Determining the degree of dependence of the agricultural production results on the volume of state financial support based on correlation and regression analysis

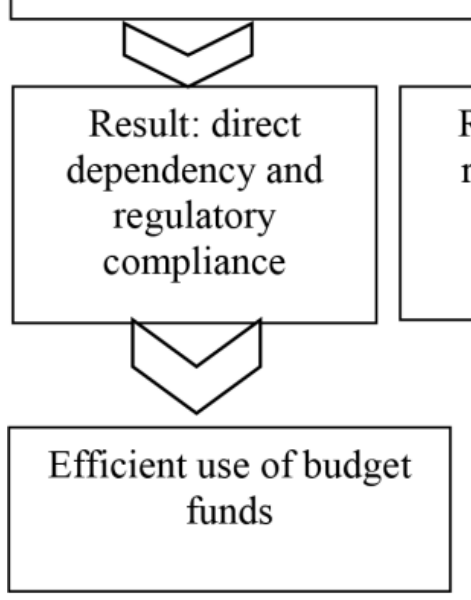

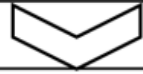

Result: inverse relationship of funds
Involvement in an independent (blinded) assessment by specialists from agricultural departments and the scientific community of agricultural universities

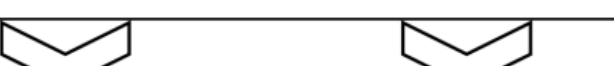

Opinion on the availability of suspicious transactions
Opinion on the absence of suspicious transactions
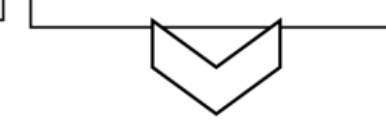

The risk of possible misuse of budget funds

Efficient use of budget funds

Appeal to the territorial authority related to the Ministry of Internal Affairs of Russia

Figure 3. Evaluation methods for the effectiveness of the development of public funds in the form of subsidies and grants by agricultural entities

\section{References}

Dadalko, V. A. (2010). Problems of counteracting the illegal economy in the field of food security in modern Russia, Problems of Economics and Legal Practice, 5, 261-264.

Gafurov, L. Kh. (2018). Methods of investigation of crimes in agriculture, Theory and practice of modern science, 10, 40. - URL: https://modernj.ru/domains_data/files/40/Gafurov\%20L.H.\%202 (access date 03.03.2020)

Khairullina, O. I., and Yarkova, T. M. (2018). Food Issue and Need for its Normative and Legal Regulation in Russia [Electronic resource], Helix, 8, 6, 4702- 4706. Access mode: 
REVISTA DE LA UNIVERSIDAD DEL ZULIA. 3a época. Año $11 N^{\circ}$ 29, 2020

Tatyana M. Yarkova /// Illegal economic phenomena in the Russian agricultural sector, 276-284

http://helix.dnares.in/2019/01/05/food-issue-and-need-for-its-normative-and-legalregulation-in-russia/ (DOI 10.29042/2018-4702-4706)

Khairullina, O. I., and Yarkova, T. M. (2019). Program-target instruments of the mechanism of state support for agriculture, Revista Amazonia Investiga, 8, 19. [Electronic resource].- Access mode: // https://www.udla.edu.co/revistas/index.php/amazonia-investiga/article/view/1361/pdf

Melnikov, K. N. (2012). Features of the identification and disclosure of crimes in the field of agriculture, Jurisprudence and practice: Bulletin of the Nizhny Novgorod Academy of the Ministry of Internal Affairs in Russia, 19. - URL: https:/cyberleninka.ru/article/n/osobennosti-vyyavleniya-i-raskrytiya-prestupleniyv-sfere-agropromyshlennogo-kompleksa (access date: 03.03.2020).

Panin, D. A. (2012). Illegal economy in the agro-industrial complex as a threat to the food security of Russia, Bulletin of the Moscow University included in the Ministry of Internal Affairs in Russia, 3, 15-16.

Ramos, B.; García, J. (2016). La propiedad industrial y su normativa vigente, Revista de la Universidad del Zulia, 7 (17), 11-25.

Repin, M. E. (2015). Description of fraudulent crimes committed in the field of agriculture, Jurisprudence and Practice: Bulletin of the Nizhny Novgorod Academy of the Ministry of Internal Affairs in Russia, 2, 30, 177-181.

Trotsenko, V. M. (2019). Counteraction to illegal processes as the basis for ensuring economic security in the agricultural sector, Moscow Economic Journal, 9, 197-204. URL: https://cyberleninka.ru/article/n/protivodei-stviya-tenevym-protsessam-kakosnova-obespecheniya-ekonomicheskoi-bezopasnosti-v-agropromyshlennomkomplekse (accessed date: 01.03.2020).

Yarkova, T. M. (2018). Social and economic availability of food for the population of the region: methodical aspect [Electronic resource], The Turkish Online Journal of Design, Art and Communication, March 2018 Special Edition, 219-225. Access mode: http://www.tojdac.org/tojdac/HOME.htmll (DOI: 10.7456/1080MSE) 